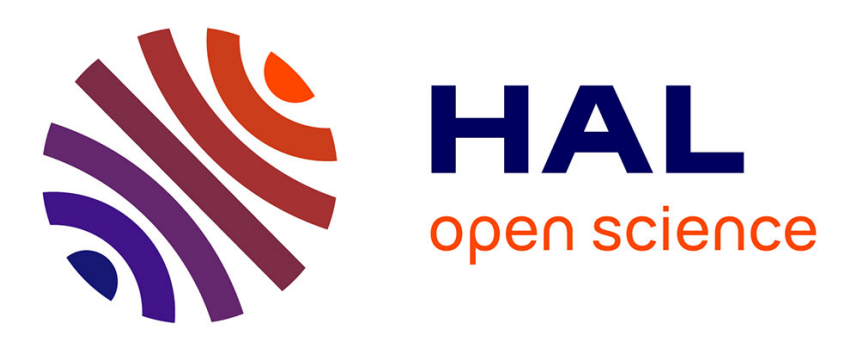

\title{
In Situ Stabilization of Trace Metals in a Copper-Contaminated Soil using P-Spiked Linz-Donawitz Slag
}

O. Negim, Michel Mench, Clémence Bes, Mikael Motelica-Heino, Fouad Amin, Philippe Le Coustumer

\section{To cite this version:}

O. Negim, Michel Mench, Clémence Bes, Mikael Motelica-Heino, Fouad Amin, et al.. In Situ Stabilization of Trace Metals in a Copper-Contaminated Soil using P-Spiked Linz-Donawitz Slag. Environmental Science and Pollution Research, 2012, 19 (3), pp.847-857. 10.1007/s11356-011-0622-1 . insu-00619352

\section{HAL Id: insu-00619352 \\ https://hal-insu.archives-ouvertes.fr/insu-00619352}

Submitted on 6 Sep 2011

HAL is a multi-disciplinary open access archive for the deposit and dissemination of scientific research documents, whether they are published or not. The documents may come from teaching and research institutions in France or abroad, or from public or private research centers.
L'archive ouverte pluridisciplinaire HAL, est destinée au dépôt et à la diffusion de documents scientifiques de niveau recherche, publiés ou non, émanant des établissements d'enseignement et de recherche français ou étrangers, des laboratoires publics ou privés. 


\title{
In Situ Stabilization of Trace Metals in a Copper-Contaminated Soil using P-Spiked Linz-Donawitz Slag
}

\author{
Negim Osama ${ }^{1}$, Mench Michel ${ }^{2}$, Bes Clémence², Motelica-Heino Mikael $^{3}$, Amin Fouad $^{4}$, Huneau \\ Frédéric $^{1}$ and Le Coustumer Philippe ${ }^{1^{*}}$
}

\begin{abstract}
${ }^{1}$ Université Bordeaux, EA4592 Géoressources \& Environnement, EGID-OASU, Allée F. Daguin, 33607 Pessac, France, * corresponding author : plc@lnet.fr, tél : +3354000 879, Fax : +3354000311

${ }^{2}$ UMR BIOGECO INRA 1202, Ecologie des Communautés, Université Bordeaux 1, Bat B2 RdC Est, avenue des Facultés, 33405, Talence, France.

${ }^{3}$ Université d'Orléans, Université François Rabelais - Tours, CNRS/INSU Institut des Sciences de la Terre d'Orléans, UMR 6113 Campus Géosciences 1A, rue de la Férollerie 41071 Orléans cedex 2, France

${ }^{4}$ Italcementi Group, CTG, Rue des Technodes, 78930, Guerville cédex, France
\end{abstract}

\section{ABSTRACT}

P-spiked Linz-Donawitz (LD) slag was used as a soil additive to improve physico-chemical soil properties and in situ stabilize $\mathrm{Cu}$ and other trace metals in a sandy $\mathrm{Cu}$-contaminated soil (630 $\mathrm{mg} \mathrm{kg}^{-1}$ soil) from a former wood preservation site. The LD slag was incorporated into the contaminated soil to consist four treatments: $0 \%(\mathrm{~T} 1), 1 \%(\mathrm{~T} 2), 2 \%(\mathrm{~T} 3)$, and $4 \%$ (T4) per air-dried soil weight. A similar uncontaminated soil was used as a control (CTRL). After a one-month reaction period, potted soils $(1 \mathrm{~kg})$ were used for a 2 -week growth experiment with dwarf beans (Phaseolus vulgaris L.). Soil pH increased with the incorporation rate of LD slag from 5.7 in the T1 soil up to 7.9 in the T4 soil. Similarly the soil electrical conductivity $\left(\mathrm{EC}\right.$, in $\mathrm{mS}^{-}$ ${ }^{1}$ ) rose from 0.15 (T1 soil) up to 1.17 (T4 soil). Bean plants grown on the T1 soil showed a high phytotoxicity. All incorporation rates of LD slag increased the root and shoot dry weight yields compared to the untreated soil (T1). The foliar Ca concentration of beans was enhanced for all LD slag-amended soils, while the foliar Mg, $\mathrm{K}$, and $\mathrm{P}$ concentrations were not increased. Foliar $\mathrm{Cu}, \mathrm{Zn}$, and $\mathrm{Cr}$ concentrations of beans decreased with the LD slag incorporation rate. The $2 \%$ incorporation rate was sufficient to obtain the highest bean growth and foliar Ca concentration, to reduce foliar $\mathrm{Cu}$ concentration below its upper critical value, and to avoid an excessive soil EC and Zn deficiency. 
Keywords: copper, chromium, Linz-Donawitz slag, Phaseolus vulgaris, phosphate, soil, remediation, trace metal, contamination.

\author{
Abbreviations: \\ Chromated copper arsenate: CCA, dry weight: DW, electrical conductivity: EC, fresh weight: FW, organic \\ matter: OM, graphite furnace atomic absorption spectrometry: GF-AAS, P-spiked Linz-Donawitz slag: LD slag \\ potentially toxic trace elements: PTTE, Thomas phosphate basic slag: TBS, X -EDS: X-ray energy dispersive \\ spectroscopy.
}

\title{
1. INTRODUCTION
}

Soil contamination by potentially toxic trace elements (PTTE) due to anthropogenic activities is of concern in many world parts (He et al., 2005; Mathieu et al., 2008). Since the $18^{\text {th }}$ century, the fungicidal $\mathrm{Cu}$ properties are recognized, and many $\mathrm{Cu}$-based wood preservatives have been widely used (Bhattacharya et al., 2002; Karjalainen et al., 2009; Mench and Bes, 2009). The volume of wood products treated with Cu-based preservatives grew exponentially during the 1970 s and 1980 s and $\mathrm{Cu}$ remains today one of the primary biocide components used to protect wood used in ground contact or fully exposed to the weather (Freeman and McIntyre, 2008). Several PTTE, i.e. As, B, Cu, Cr, and $\mathrm{Zn}$ can occur in excess in contaminated soils at wood preservation sites, depending on $\mathrm{Cu}$-based preservatives used against insects and fungi, which may result in soil ecotoxicity and PTTE dispersion through natural agencies (Bhattacharya et al., 2002; Kumpiene et al., 2008; Girouard and Zagury, 2009; Mench and Bes, 2009; Bes et al., 2010). Consequently, important aims are to remove (Gabrielli dos Santos et al., 2010; Kolbas et al., 2011) or to stabilize such PTTE in excess in these contaminated soils to minimise pollutant linkages such as root exposure, plant uptake, and leaching from the root zone (Mench et al., 2010). Several in situ stabilization techniques of PTTE in contaminated soils have been developed by incorporating amendments which reduce their labile pool, their root uptake and soil ecotoxicity (Mench et al. 2006; Kumpiene et al. 2008). In particular neutralizing agents in the form of alkaline materials have been added to acid soils to ameliorate their physico-chemical properties and reduce metal phytoavailability (Brallier et al., 1996; Brown et al., 1997; Bolan and Duraisamy, 2003; Gray et al., 2006; Tlustoš et al., 2006). Many alkaline materials are available to neutralize the soil acidity including calcite $\left(\mathrm{CaCO}_{3}\right)$, burnt lime $(\mathrm{CaO})$, slaked lime $\left(\mathrm{Ca}(\mathrm{OH})_{2}\right)$, dolomitic limestone $\left(\mathrm{CaMg}\left(\mathrm{CO}_{3}\right)\right.$, and slag $\left(\mathrm{CaSiO}_{3}\right)$ (Bolan and Duraisamy, 2003). They can reduce the negative effects of PTTE such as $\mathrm{As}, \mathrm{Cr}, \mathrm{Cu}, \mathrm{Pb}, \mathrm{Cd}$, and $\mathrm{Zn}$, and improve the quality of 
contaminated soils (Mench et al., 2000; Oste et al., 2002; Bolan and Duraisamy, 2003; Adriano et al., 2004; Pérez de Mora et al., 2005; Raicevic et al., 2005; Kumpiene et al., 2006; 2008).

According to changes in soil $\mathrm{pH}$, alkaline materials may be effective to induce metal hydrolysis reactions and/or co-precipitation with carbonates and to act as a precipitating agent for metals in the soil solution (Tyler and McBride, 1982; Mench et al., 1998; Singh and Oste, 2001; Bes and Mench, 2008). Liming of acid soils decreased the soluble fraction and plant uptake of $\mathrm{Ni}, \mathrm{Cd}, \mathrm{Zn}$ and $\mathrm{Cu}$ as well as increased the crop yield (Brallier et al., 1996; Krebs et al., 1998; Singh and Oste, 2001). Alkaline materials incorporated into Cucontaminated soils improved the plant growth and reduced $\mathrm{Cu}$ concentration in the soil pore water (Fessenden and Sutherland, 1979; Bes and Mench, 2008). The incorporation of $\mathrm{Ca}\left(\mathrm{H}_{2} \mathrm{PO}_{4}\right)_{2}$ and $\mathrm{CaCO}_{3}$ into a multi-metal contaminated soil decreased the extractable concentrations of $\mathrm{Cd}, \mathrm{Cu}, \mathrm{Pb}, \mathrm{Ni}$, and $\mathrm{Zn}$ by more than $96 \%$ (Wang et al., 2001). Phosphogypsum improved soil properties such as $\mathrm{pH}$, soil electrical conductivity (EC), cation exchange capacity (CEC), exchangeable $\mathrm{Ca}, \mathrm{Mg}$, and metal phytoavailability, and increased the crop yield (Alva and Sumner, 1990). Phosphates and related materials such as phosphoric acid, phosphate rocks, and synthesized apatites have been successfully applied to stabilize $\mathrm{Pb}, \mathrm{Cd}, \mathrm{Zn}$, and $\mathrm{Cu}$ in contaminated soils, sediments and solid wastes, reducing their phytoavailability, their mobility in soils, and subsequently their leaching from the root zone to the groundwater (Bolan et al., 2003; Liu and Zhao, 2007). Phosphate minerals have the potential to sorb and /or co-precipitate trace metals (Barrow, 1987; Pierzynski and Schwab, 1993; Xu et al., 1994; Ma, 1996; Mench et al., 1998). The use of hydroxyapatite for the in situ stabilization of metals ( $\mathrm{Zn}, \mathrm{Pb}, \mathrm{Cu}$, and $\mathrm{Cd})$ in contaminated soils decreased the exchangeable metal contents in soil, promoted plant growth and reduced the foliar metal concentrations of plants (Boisson et al., 1999a, b). In that case, the stabilization of trace metals of the soils could occurre through cations exchanges or by a dissolution - reprecipitation mechanisms. Iron phosphate (vivianite) incorporated into $\mathrm{Cu}$-contaminated soils likely induced precipitation and adsorption processes decreasing available soil $\mathrm{Cu}$ (Liu and Zhao 2007).

Slags, which usually consist of $\mathrm{Ca}, \mathrm{Al}, \mathrm{Si}, \mathrm{Fe}$, and other metal oxides, are alkaline by-products of metallurgical processes and residues of incineration processes. Several slag types have been used as amendment for metal-contaminated soils (Mench et al, 1994a, 2000), but the use and environmental assessment of LinzDonawitz (LD) slags is more recent (Proctor et al., 2002; Gahan et al., 2009; Yilmaz et al., 2010). Copper mainly precipitates with hydroxide dissolved from the slag rather than adsorbs on the slag surface (Kim et al., 2008). Blast-furnace slag is an effective sorbent for $\mathrm{Cu}, \mathrm{Zn}, \mathrm{Ni}$, and $\mathrm{Pb}$ ions for a wide range of ion concentrations and pH values (Dimitrova, 1996; Dimitrova and Mehandjiev, 1998). The use of blast furnace slag to correct the soil 
acidity promoted root length, shoot dry matter (DM) and grain yield (Carvalho-Pupatto et al., 2004). Calcium silicate slag can reduce the soil acidity, increase $\mathrm{Ca}, \mathrm{Mg}$, Si and P availability (Besga et al., 1996; Barbosa Filho et al., 2004), and lessen exchangeable soil Al, Mn, $\mathrm{Cu}$, and $\mathrm{Zn}$ (Besga et al., 1996). Slag application in a tea garden and rice field soils increased the soil pH, shoot DM yield and P and Mn uptake (Ali and Shahram, 2007); plant $\mathrm{Fe}$ and $\mathrm{K}$ uptake increased in the rice field, while $\mathrm{K}$ uptake decreased and Fe uptake was not changed in the tea garden. Thomas phosphate basic slag used in several contaminated soils cut down the mobility and phytoavailability of $\mathrm{Cd}, \mathrm{Zn}, \mathrm{Pb}$, and $\mathrm{Cu}$, and can promote plant growth (Mench et al., 1994a, b; Bes and Mench, 2008).

This study aimed at determining (1) if the incorporation of a P-spiked LD slag into a Cu-contaminated topsoil from a French wood preservation site can improve soil properties, i.e. pH and EC, and (2) the LD addition rate which promotes the growth of bean plants and optimizes foliar mineral concentrations in their primary leaves.

\section{MATERIAL and METHODS}

\subsection{Soils}

The site (6 ha) is located in Gironde, SW France (N 444․353, W 000³0.938) and has been used for over a century to preserve and store timbers, posts and utility poles (Mench and Bes, 2009). Creosote and $\mathrm{Cu}$ based salts (i.e. mainly $\mathrm{CuSO}_{4}$, and chromated copper arsenate to a lesser extent) have been successively used as wood preservatives. Assessment of established vegetation and site characteristics were previously reported (Mench and Bes, 2009; Bes et al., 2010). Anthropogenic soils are developed on an alluvial soil (Fluviosol). Soil investigation pits $(0-1.5 \mathrm{~m})$ have demonstrated a major contamination of topsoils with $\mathrm{Cu}$ due to wood washing (Table 1) with spatial variation (65 to $2400 \mathrm{mg} \mathrm{Cu} \mathrm{kg}^{-1}$ soil DW) whereas total soil As and Cr, i.e. 10-53 mg As and 20-87 $\mathrm{mg} \mathrm{Cr} \mathrm{kg}^{-1}$ in topsoils, remained relatively low in all soil layers (Mench and Bes, 2009). The contaminated topsoil $\left(0-25 \mathrm{~cm}, 50 \mathrm{~kg}\right.$ from a $4 \mathrm{~m}^{2}$ area, Table 1) was collected with a stainless spade near the sub-site P7 where there are evidences that polycyclic aromatic hydrocarbons (PAH) in the topsoil are below the French guideline values for residential and industrial uses (Mench and Bes 2009). A similar uncontaminated Fluviosol soil was sampled $(0-25 \mathrm{~cm}, 10 \mathrm{~kg})$ in a kitchen garden (Gradignan, Gironde, France) and used as a control soil (CTRL, Table 1). Soils were air-dried, homogenized and sieved (2 mm). Soil material (50 g) was used for particle size distribution analysis by sieving and pipette methods (Richards, 1954; Jackson, 1969). The 
soil $\mathrm{pH}$ was determined in 1:1 soil:water suspension using a glass electrode $\mathrm{pH}$ meter (Jackson, 1967). The soil EC was measured in 1:1 soil:water suspension with a conductivity meter (WTW 340i), Jackson, 1967). Total nitrogen was determined at the INRA, Laboratoire d'Analyses des Sols (LAS), Arras, France using standard methods (INRA LAS, 2007). The organic matter (OM) content was determined by a modified Walkely-Blake method; $0.5 \mathrm{~g}$ air-dried soil was placed in a $500 \mathrm{~mL}$ conical flask and mixed with $10 \mathrm{~mL}$ of $0.17 \mathrm{M} \mathrm{K}_{2} \mathrm{Cr}_{2} \mathrm{O}_{7}$, followed by addition of $20 \mathrm{~mL}$ of $\mathrm{H}_{2} \mathrm{SO}_{4}, 200 \mathrm{~mL}$ of water, $10 \mathrm{~mL}$ of $\mathrm{H}_{3} \mathrm{PO}_{4}$ and one $\mathrm{mL}$ of diphenylamine indicator. The contents were backtitrated with $0.5 \mathrm{M} \mathrm{FeSO}{ }_{4} .7 \mathrm{H}_{2} 0$. The OM estimation $( \pm 7-8 \%)$ assumes that $77 \%$ of the organic carbon is oxidized by the method and that soil OM contains 58\% C (Jackson, 1967). The total cation exchange capacity (CEC) was determined by the cobaltihexamine chloride method (Ciesielski and Sterckeman, 1997). Total concentrations of trace elements in soils were determined by inductively coupled plasma emission (ICP-AES, Ultimal from Jobin-Yvon, Horiba) after wet digestion in $\mathrm{HF}$ and $\mathrm{HCIO}_{4}(\mathrm{AFNOR}$ NF X 31-147, Ciesielski et al., 1997). Table 1 gives the main physico-chemical properties of the contaminated (T1) and control (CTRL) soils. Compared to the control soil (CTRL), the contaminated soil (T1) displayed a high value for total soil $\mathrm{Cu}$ (Table 1). It largely exceeded $\mathrm{Cu}$ background concentrations in French sandy soils and the threshold value justifying a contamination assessment, i.e. $35 \mathrm{mg} \mathrm{Cu} \mathrm{kg-1} \mathrm{(Baize,} \mathrm{1997)} \mathrm{(Table} \mathrm{1).} \mathrm{Total}$ soil As and $\mathrm{Cr}$ in the contaminated soil were similar to upper whisker values for French sandy soils. The composition of the contaminated soil mostly reflected the use of $\mathrm{Cu}$-based wood preservatives.

The X-EDS maps showed a higher content of P, widely distributed, in the LD slag than in the initial slag (Fig. 1). The LD slag consisted of a complex mixture of Ca phases, i.e. Ca silicates such as Larnite, Ca ferroaluminates such as Brownmillerite and Sreboldoskite, calcite and hydrated calcite such as Portlandite, $\mathrm{Fe}$ oxides such as Wustite, Si oxide (silica), and P phases such as oxides and phosphates. The phosphate crystals in the LD slag mainly belonged to the Analcime and Apatite families, which are wellknown to sorb trace metals and to act as P fertilizer for plant growth.

\subsection{Soil amendment}

The Linz-Donawitz (LD) slag from electric steel furnace, also known as basic oxygen furnace, was furnished by the Centre Technique et de Promotion des Laitiers Sidérurgiques (CTPL, La Plaine Saint-Denis, France). This by-product of the steelmaking industry generally contained about $30 \% \mathrm{Ca}, 20 \% \mathrm{Fe}, 15 \% \mathrm{SiO}_{2}, 5 \%$ $\mathrm{Mg}, 5 \% \mathrm{Al}, 1.4 \% \mathrm{P}$ and trace metals such as $\mathrm{Cr}, \mathrm{V}$, and $\mathrm{Ba}$ in low concentrations (Gahan et al. 2009; Yilmaz et al., 2010). These elements are combined to form a mix of calco-alumina silicates, iron oxides, lime and other 
metal oxides which usually sorb trace metals. The initial Linz-Donawitz slag was chemically modified by precipitation of mineral phosphates to increase its P content (F. Amin, 1993) and henceforth called LD slag in the following text. The X-EDS maps were performed on two thin blades of initial and LD slags using a JEOL SEM (6400) equiped with an Oxford X-EDS detector. Total contents of major elements in the LD slag were determined by atomic absorption spectrophotometry (Perkin-Elmer, AAnalyst400) after sample digestion in pure HF solution (1M). Arsenic was determined by GF-AAS (norm NF EN ISO 15586, T90-119) after digestion with aqua regia (norm NF EN 13346). Other trace elements were analysed by ICP-AES (norm NF EN ISO 11885) after total digestion (norm NFX31-147, Cieselski et al., 1997). The pH and EC of LD slag were measured using a glass electrode $\mathrm{pH}$ meter and a conductivity meter (WTW 340i). The LD slag incorporation into the contaminated soil significantly increased the soil $\mathrm{pH}$ and EC (Fig. 2). The soil pH varied from 5.7 in the untreated contaminated soil (T1) to $7,7.4$ and 7.9 in the T2, T3, and T4 soils, respectively (Fig. 2a). Soil pH in the T3 soil and the control soil (7.41) were similar. The soil EC (in mS cm-1) increased from 0.15 (T1) to 0.47 , 0.51, and 1.17 for the T2, T3, and T4 soils, respectively (Fig. 2b). The soil EC was higher in the T2, T3, and T4 soils than in the control soil $(0.41 \mathrm{mS} \mathrm{cm}-1)$. These increases in soil $\mathrm{pH}$ and EC in all LD slag-amended soils were related to the composition of $\mathrm{LD}$ slag which released $\mathrm{P}, \mathrm{Ca}$, and alkaline products. A relatively small LD slag amount induced a rapid change of the soil pH and EC as for the liming of acid soils (Su and Evans, 1996). Additionally, liming of metal-contaminated soils increased the net negative charge of variably charged soil colloids such as clays and OM (Gray et al., 2006). Increases in soil pH and EC after slag incorporation have been previously reported (Alva and Sumner, 1990), notably for basic slag with and without NPK fertilization (Pinto et al., 1995; Besga et al., 1996; Jamali and Forghani, 2008) and for Thomas basic slag (TBS) in a similar Cucontaminated soil from a wood preservation site (Bes and Mench, 2008). Our results confirmed that LD slag incorporation in an acid, contaminated soil can ameliorate its properties such as soil pH and EC. However soil EC in the T4 soil (Fig. 2b) exceeded the suitable values for plant growth, i.e. $0-0.45 \mathrm{mS} \mathrm{cm-1} \mathrm{(Omafra,} \mathrm{2008).}$

\subsection{Pot experiment}

The LD slag was incorporated into the contaminated soil at increasing rate (in \% by air-dried soil weight) to consist four soil treatments, i.e. $0 \%(\mathrm{~T} 1), 1 \%(\mathrm{~T} 2), 2 \%(\mathrm{~T} 3)$, and $4 \%(\mathrm{~T} 4)$. Three replicates $(1 \mathrm{~kg}$ air-dried soil) for each treatment were homogenised by rotation in 2-L plastic flasks, and transferred into 1.3-L plastic pots. The control soil (CTRL) was treated in the same way. After the LD slag incorporation, the soil moisture content was raised to $70 \%$ of the water holding capacity (WHC, $10 \%$ of air-dried soil weight) by 
manual irrigation with distilled water and soils were allowed to react for four weeks at $20^{\circ} \mathrm{C}$. Thereafter, four dwarf beans (Phaseolus vulgaris L. cv. vroege Limburgs) were sown in all pots. Plants were cultivated in the laboratory under controlled environmental conditions: illumination $12 \mathrm{~h}$ light/12 h darkness regime, intensity $150 \mu \mathrm{mol} \mathrm{m} \mathrm{m}^{-2}$, temperature $25^{\circ} \mathrm{C} / 22^{\circ} \mathrm{C}$, and $50 \%$ relative humidity. Pots were arranged in a fully randomised block design on a bench and watered daily with deionised water (at 50\% WHC) without loss from drainage. The plant growth was monitored on a daily basis using an index based on plant development steps for two weeks and then plants were harvested. Phenotype traits, i.e. the fresh weight of roots, shoots and primary leaves, were measured. Plant parts were washed with deionised water (2 times) and distilled water, dried in an oven at $70{ }^{\circ} \mathrm{C}$, and weighted to determine the DW biomass production. Plant samples $(0.5 \mathrm{~g})$ were wet digested in $5 \mathrm{~mL} 14 \mathrm{M}$ $\mathrm{HNO}_{3}, 2 \mathrm{~mL} \mathrm{H} \mathrm{O}_{2}$ and $1 \mathrm{~mL}$ distilled water at $180^{\circ} \mathrm{C}$ in PFA (perfluoroalkoxy copolymer resin) tubes under microwaves (MarXpress, CEM) corresponding to an oxidation step from a pure chemical point of view. Mineral composition in the plant digests were determined by ICP-AES (Ultima, Jobin Yvon Horiba, Longjumeau, France). Soil samples were taken from all pots to measure the soil $\mathrm{pH}$ and EC as described above.

\section{$\underline{2.4 \text { Statistical analysis }}$}

All analytical determinations were triplicated. For the pot experiment, soil and plant data were statistically analysed (ANOVA, Kruskall-Wallis and Tukey test) with the SAS software (version 9.1) to evaluate changes in soil properties (soil pH and EC), root and shoot yields, mineral concentrations of primary leaves and their mineral mass $\left[\mu \mathrm{g}\right.$ plant ${ }^{-1}$, calculated by multiplying the biomass of primary leaves $\left(\mu \mathrm{g}\right.$ DW plant $\left.{ }^{-1}\right)$ by their element concentration $\left.\left(\mu \mathrm{g} \mathrm{kg}^{-1} \mathrm{DW}\right)\right]$.

\section{RESULTS and DISCUSSION}

\subsection{Effect of LD slag on Plants}

\subsubsection{Effect of the $L D$ slag incorporation on the shoot $D W$ yield}

The shoot DW yield of beans peaked for the control soil and displayed the lowest value for the untreated soil (T1) (Fig. 3). This confirmed that soils from the sub-site P7 negatively impact bean plants (Bes and Mench, 2008). The shoot DW yield rose (3 - 4 times) in all LD slag-amended soils compared to the T1 soil. Numerically, higher values occurred at the $2 \%$ and $4 \%$ addition rates, but differences were not significant between the T2, T3 and T4 soils. Values for the T3 and T4 treatments represented $61 \%$ and $67 \%$ compared to 
the CTRL treatment. Positive effects of the LD slag incorporation on soil properties such as soil $\mathrm{pH}$ and EC and labile nutrient pool would contribute to promote the bean growth. Our results agreed with previous findings showing that slag incorporation corrects soil acidity and promotes shoot and grain DW yields (Alva and Sumner, 1990; Barbosa Filho et al., 2004; Carvalho-Pupatto et al., 2004; Bes and Mench, 2008). Best soil pH values for bean growth range from 6.0 to 7.5 (Gardener's Network, 2009), and the T2, T3 and CTRL values fell in this range (Fig. 2a). In addition, the soil EC values suitable for plant growth vary between 0 and $0.45 \mathrm{mS} \mathrm{cm}^{-1}$ whereas values in the $0.46-0.7 \mathrm{mS} \mathrm{cm}$ range may decrease the plant growth and cause a slight to severe damage to salt sensitive plants (Omafra, 2008). That soil EC peaked in the T4 soil (Fig. 2b) may counteract the potential beneficial effect related to the increasing incorporation rate and explain that $\mathrm{T} 3$ and $\mathrm{T} 4$ soils did not differ for shoot DW yield (Fig. 3).

\subsubsection{Effect of $L D$ slag incorporation on the root $D W$ vield}

Root DW yield increased for all LD slag-amended soils compared to the untreated contaminated soil (T1) (Fig. 4). Root DW yield peaked for the 4\% incorporation rate (T4 treatment) and its value was even higher than for the control soil. Root DW yield correlated to the LD slag incorporation rate and the value distribution fitted well with a $2^{\text {nd }}$-order polynomial function $\left(\mathrm{R}^{2}=0.97\right)$. Root DW yield increased 3 and 3.5 times in the $\mathrm{T} 3$ and T4 treatments, respectively, compared to the untreated soil (T1). These results confirmed previous studies reporting that slag application to correct soil acidity increases the root biomass (Carvalho-Pupatto et al., 2004; Bes and Mench, 2008). In contrast TBS incorporated into several contaminated soils did not increase the production of plant biomass but reduced the mobility and phytoavailability of $\mathrm{Cd}, \mathrm{Zn}$, and $\mathrm{Pb}$ (Mench et al., 1994a, b).

\subsubsection{Effect of the LD slag incorporation on the foliar concentrations and mineral mass of trace elements}

Foliar $\mathrm{Al}, \mathrm{Cu}, \mathrm{Cr}$, and $\mathrm{Zn}$ concentrations of beans decreased for all LD slag-amended soils compared to the untreated contaminated soil (Table 3). The decrease in foliar metal concentrations may be due to the release of $\mathrm{Ca}$ and $\mathrm{P}$ by the $\mathrm{LD}$ slag, increase in soil $\mathrm{pH}$ and metal sorption, Ca competition with metals for root uptake, and the dilution effect due to the increased biomass of primary leaves. Foliar Al mass ranged from 2.6 (T1 plants) to $5.9 \mu \mathrm{g}_{\text {plant }}{ }^{-1}$ (CTRL plants) but differences were not significant (Table 4). In the literature, liming on acid soil surface increased the soil $\mathrm{pH}$ and reduced $\mathrm{Al}$ phytotoxicity (Brown et al., 2008). In most cases $\mathrm{P}$ 
addition to acid soils resulted in Al precipitation (Wright, 1937). Calcium silicate slag decreased both soil acidity and exchangeable $\mathrm{Al}$ in soils (Besga et al., 1996).

Foliar $\mathrm{Cu}$ concentrations varied between 6.2 (CTRL plants) and $35.7 \mathrm{mg} \mathrm{kg}^{-1} \mathrm{DW}$ (T1 plants) (Table 3) and ranked in the following order: $\mathrm{T} 1>\mathrm{T} 2>\mathrm{T} 3>\mathrm{T} 4>\mathrm{CTRL}$. Foliar $\mathrm{Cu}$ concentrations in the T3 and T4 plants decreased 2 and 2.5 times, respectively, compared to the T1 plants. Frequent values for Cu concentration in bean primary leaves were exceeded in all treatments except CTRL (Table 3). Upper critical foliar Cu concentration for beans is 15-30 mg Cu kg-1 DW (MacNicol and Beckett, 1985). This explained that bean growth was limited on the T1 soil (Fig. 3 and 4). Foliar Cu mass varied from 1.9 (CTRL plant) to 3.4 (T3 plants) $\mu \mathrm{g}_{\text {plant }}{ }^{-1}$ (Table 4). The LD slag incorporation into the contaminated soil may reduce $\mathrm{Cu}$ mobility by precipitation due to increased soil $\mathrm{pH}$ and/or sorption with LD slag and native soil compounds. At $\mathrm{pH} 7, \mathrm{Cu}$ tends to precipitate in the forms of carbonate and hydroxide (Sipos et al., 2008). Such pH value was reached in all LD slag-amended soils (Fig. 2a). Generally, $\mathrm{Cu}$ was render less soluble by precipitation of $\mathrm{Cu}$ carbonates and oxy-hydroxides, ion exchange, and formation of ternary cation-anion $\left(\mathrm{SO}_{4}, \mathrm{PO}_{4}\right)$ complexes on the surface of $\mathrm{Fe}$ and $\mathrm{Al}$ oxy-hydroxides (Kumpiene et al., 2008). Kim et al. (2008) suggested that $\mathrm{Cu}$ precipitates with hydroxides dissolved from slag rather than adsorbs on the slag surface. Liu and Zhao (2007) reported that the application of iron phosphate decreased $\mathrm{Cu}$ availability in $\mathrm{Cu}$-contaminated soils by precipitation and adsorption processes. Usually incorporation of alkaline materials in acid soils decreased $\mathrm{Cu}$ concentration in soil solution and plants and increased crop yield (Brallier et al. 1996; Krebs et al., 1998; Singh and Oste, 2001; Bes and Mench, 2008).

Foliar $\mathrm{Cr}$ concentrations ranged from 0.4 (CTRL plants) to $6.0 \mathrm{mg} \mathrm{kg}^{-1} \mathrm{DW}$ (T1 plants) with the following order: T1 > T2, T3, T4 and CTRL. Foliar Cr concentration in the T1 plants exceeded frequent values in primary leaves of dwarf beans grown on uncontaminated soils, i.e. 0.13-1.7 $\mathrm{mg} \mathrm{Cr} \mathrm{kg}^{-1} \mathrm{DW}$ (Mench et al., 1996). The Cr mobility in soils is decreased by the presence of OM and divalent iron (Kumpiene et al., 2008). The higher $\mathrm{OM}$ content in the control soil (Table 1) may contribute to the lowest foliar Cr concentration in CTRL plants (Table 3). The LD slag also contained Fe and Mn oxides (Table 2). Kumpiene et al. (2006) reported that the incorporation of zerovalent iron grit into a CCA-contaminated soil, which resulted in newlyformed Fe and Mn oxides, reduced shoot $\mathrm{Cr}$ concentration by $95 \%$. At $\mathrm{pH}$ values greater than 5 , such as in the LD slag amended soils (Fig. 2a), the low Cr(III) hydroxyl solubility and its retention on soil surfaces such as iron oxides limits its bioavailability and mobility in soils (Fendorf, 1995). That foliar Cr concentration was higher for the T1 plants compared to all other plants (Table 3) was also assumed related to decrease in shoot DW yield (Fig. 2). Foliar Cr mass did not significantly differ across the soil treatments (Table 4). 
Foliar Zn concentrations ranged between 2.9 (T4 plants) and $10.9 \mathrm{~g} \mathrm{~kg}^{-1} \mathrm{DW}$ (CTRL plants) and were lower than frequent values for beans grown on uncontaminated soils (Table 3). According to Mench et al. (2000), increase of soil $\mathrm{pH}$ reduces $\mathrm{Zn}$ availability in the soil solution and increase in bean leaf yield cuts down foliar $\mathrm{Zn}$ concentration. The lowest foliar $\mathrm{Zn}$ concentration occurred in the T4 plants, with a decrease of 3.5 and 3.8 times compared to the T1 and control plants, respectively (Table 3 ). At the $4 \%$ incorporation rate, LD slag may induce an excessive Zn sorption and low Zn supply may limit bean growth compared to CTRL (Fig. 3). In previous findings, TBS incorporation into contaminated soils decreased $\mathrm{Zn}$ mobility and phytoavailability (Mench et al., 1994a, b). Foliar Zn mass did not differ across the LD slag-amended and contaminated soils but peaked in the control soil (Table 4).

\subsubsection{Effect of the LD slag incorporation on the foliar nutrient concentrations and mass}

Foliar Ca concentrations ranged between 2.5 (T1 plants) to $21.3 \mathrm{~g} \mathrm{~kg}^{-1} \mathrm{DW}$ (CTRL plants) (Table 3) and significantly increased in all LD slag-amended soils compared to the T1 soil. Foliar Ca concentration peaked in the T3 and T4 plants, being 7.9 and 7.6 times higher compared to the T1 plants, respectively. However foliar Ca concentration did not significantly differ between the T2, T3, T4 and CTRL plants. Foliar Ca concentration in plants frequently ranges between 1 and $50 \mathrm{~g} \mathrm{~kg}^{-1} \mathrm{DW}$ (Marschner, 1995) and Ca concentration in the primary leaves of dwarf beans grown on uncontaminated soils varies between 6.4 and $28 \mathrm{~g} \mathrm{~kg}^{-1} \mathrm{DW}$ (Table 3, Mench et al., 1996). Low foliar $\mathrm{Ca}$ concentration vs. foliar $\mathrm{Cu}$ concentration especially in the $\mathrm{T} 1$ plants can limit bean growth, Ca sub-cellular homeostasis and the detoxification of oxidative stress (Cuin, 2006). The TBS incorporation into a $\mathrm{Cu}$-contaminated soil from a wood preservation site also increased the foliar Ca concentration and reduced the foliar $\mathrm{Cu}$ one in beans (Bes and Mench, 2008). Foliar $\mathrm{Ca}$ mass significantly increased in all LD slag-amended plants compared to the T1 plants, peaked in the CTRL plants, and was the lowest in the T1 plants (Table 4). Increased foliar Ca mass in plants from LD slag-amended soils may contribute to enhance pectin methylesterase functioning (Micheli, 2001) and $\mathrm{Cu}$ sorption by various ligands (Pilon et al., 2006) and may reduce perturbations in $\mathrm{Ca}^{2+}$ homeostasis and effects of oxidative stress (Cuin, 2006).

Foliar Mg concentration was lower in all plants from LD slag amended soils than in the T1 and CTRL plants (Table 3). It varied from 1.5 (T4 plants) to $3.0 \mathrm{~g} \mathrm{Mg} \mathrm{kg} \mathrm{DW}^{-1}$ (T1 plants). Lower shoot DW yield in the T4 plants compared to the CTRL plants (Fig. 3) may be partly related to a low foliar Mg concentration in the T4 plants, which was below the frequent values (Table 3). Generally, Mg concentrations in plants range between 1.5 and $3.5 \mathrm{~g} \mathrm{~kg}^{-1}$ DW (Marschner, 1995). The increases in leaf biomass (Fig. 3) and foliar Ca concentration (Table 
3) for the $\mathrm{T} 3$ and $\mathrm{T} 4$ plants may contribute to reduce their foliar Mg concentration. Foliar Mg mass was higher in the CTRL plants than in other ones (Table 4).

Foliar P concentrations varied from 2.3 (T4 plants) to $5.3 \mathrm{~g} \mathrm{~kg}^{-1}$ DW (CTRL plants) and ranked in the following order: CTRL, T1 > T2 > T3, T4 (Table 3). The P concentration in the primary leaves of dwarf beans grown on uncontaminated soils usually ranged between 1.6 and $6 \mathrm{~g} \mathrm{~kg}^{-1} \mathrm{DW}$ (Mench et al., 1996). The highest foliar P concentration in CTRL plants may result from P supplied by OM decay in the control soil and its past $\mathrm{P}$ fertilization. High foliar P concentration in the T1 plants (Table 3) may be related both to low soil $\mathrm{pH}$ and biomass production. In acid soils the $\mathrm{P}$ availability of TBS is similar to that of other water soluble $\mathrm{P}$ fertilizers (Sinaj et al., 1994). However the LD slag despite their phosphatation did not promote foliar P concentration (Table 3). Decreased foliar P concentrations with increasing LD slag incorporation rate would be related to increases in soil pH (Fig. 2a), phosphate sorption, soil Ca availability, and plant biomass (Fig. 3 and 4). Pinto et al. (1995) reported that slag addition in acid soil increases exchangeable soil $\mathrm{Ca}$ and $\mathrm{Ca}$ concentration in soil solution. Due to the LD slag composition, and notably phosphate sorption and precipitation with cations such as $\mathrm{Ca}, \mathrm{Fe}$ and $\mathrm{Al}$, phosphates would be less available in the soil solution for root uptake. The potential chemical mechanisms responsible of such trend could be a pure phosphate sorption or a phosphate complexation at the solid/liquid interface which could be precise by a specific study. The foliar P mass was higher in the CTRL plants than in all other ones (Table 4).

Foliar $\mathrm{K}$ concentrations (in $\mathrm{g} \mathrm{kg}^{-1} \mathrm{DW}$ ) were in the 13.0 (T2 plants) - 21.9 (T1 plants) range and decreased in the T2 and T3 plants (Table 3). Generally, critical K concentrations in plants range between 20 and $50 \mathrm{~g} \mathrm{~kg}^{-1}$ DW (Marschner, 1995), while the $\mathrm{K}$ concentration in the primary leaves of dwarf beans grown on uncontaminated soils varied between 13 and $22 \mathrm{~g} \mathrm{~kg}^{-1}$ DW (Mench et al., 1996). For all soil treatments, foliar K concentration of bean plants fell in this range (Table 3). Foliar K mass increased in the T3 and T4 plants compared to the T1 plants (Table 4). Pinto et al. (1995) suggested that slag application in an acid soil decreased soil exchangeable $\mathrm{K}$ due to the CEC increase. Based on foliar K concentration and mass, decrease in $\mathrm{K}$ supply was not marked here and changes in foliar $\mathrm{K}$ concentration were more related to the increases of root and shoot yields in plants grown on LD slag amended soil (Fig. 3 and 4).

\section{CONCLUSION}

Linz-Donawitz (LD) slag is an alkaline by-product from electric steel furnace with a potential for ameliorating physico-chemical soil properties and metal stabilization in contaminated soils. A LD slag spiked with $\mathrm{P}$ was incorporated at increasing rates $(0 \%, 1 \%, 2 \%$, and $4 \%)$ into an acid, sandy $\mathrm{Cu}$-contaminated soil (630 
$\mathrm{mg} \mathrm{Cu} \mathrm{kg}{ }^{-1}$ ) from a wood preservation site. Depending on the incorporation rate, the soil $\mathrm{pH}$ was increased from 5.7 in the untreated contaminated soil up to 7.9 in the $4 \%$ LD slag-amended soil. Similarly, the soil EC (in mS $\mathrm{cm}^{-1}$ ) rose from 0.15 in the untreated contaminated soil up to 1.17 in the $4 \%$ LD slag-amended soils. The LD slag incorporation increased both root and shoot DW yields of bean plants for all amended soils compared to the untreated contaminated soil. Compared to plants grown in the untreated contaminated soil, foliar $\mathrm{Cu}, \mathrm{Al}, \mathrm{and} \mathrm{Cr}$ concentrations decreased in all plants grown in the amended soils and foliar Zn concentration at the 4\% LD slag rate. Foliar Ca concentration and mass in plants were enhanced for all amended soils compared to the untreated contaminated soil. Foliar $\mathrm{Mg}$ and $\mathrm{P}$ concentrations and masses in plants were not enhanced by LD slag incorporation into the $\mathrm{Cu}$-contaminated soil. Both foliar $\mathrm{K}$ concentration and mass increased in beans at the $2 \%$ and 4\% LD slag incorporation rates. These rates resulted in the highest bean growth and foliar Ca concentrations and the lowest foliar $\mathrm{Cu}$ ones. However the $4 \%$ incorporation rate reduced too much the foliar $\mathrm{Zn}$ concentration. Foliar $\mathrm{Cu}$ mass of beans was higher in all amended soils than in the contaminated soil, notably due to the restoration of root and shoot DW yields.

\section{REFERENCES}

Adriano DC, Wenzel WW, Vangronsveld J, Bolan NS (2004) Role of assistednatural remediation in environmental cleanup. Geoderma 122, 2-4:121-142

Ali MT, Shahram SH (2007) Converter slag as a liming agent in the amelioration of acidic soils. International Journal of Agriculture and Biology 9, 5:715-720

Alva AK, Sumner ME (1990) Amelioration of acid soil infertility by phosphogypsum. Plant and Soil 128, $2: 127-129$

Amin F (1993) Etude de la fixation du phosphore sur des matériaux naturels et artificiels. Thèse, Université of Poitiers

Baize D (1997) Un point sur les teneurs totales des éléments traces métalliques dans les sols, INRA Editions, Paris, France

Barbosa Filho MP, Zimmermann FJP, Da Silva OF (2004) Influence of calcium silicate slag on soil acidity and upland rice grain yield. Cienciae Agrotecnologia 28, 2:323-331

Barrow NJ (1987) The effects of phosphate on zinc sorption by a soil. Journal of Soil Science 38, 3:453-459

Bhattacharya P, Mukherjee AB, Jacks G, Nordqvist S (2002) Metal contamination at a wood preservation site: characterisation and experimental studies on remediation. The Science of the Total Environment 290:165-180 
Bes C, Mench M (2008) Remediation of copper-contaminated topsoils from a wood treatment facility using in situ stabilisation. Environmental Pollution 156, 3:1128-1138

Bes C, Mench M, Aulen M, Gasté H, Taberly J (2010) Spatial variation of plant communities and shoot Cu concentrations of plant species at a timber treatment site. Plant Soil 330:267-280

Besga G, Pinto M, Rodriguez M (1996) Agronomic and nutritional effects of Linz-Donawitz slag application to two pastures in Northern Spain. Nutrient Cycling in Agroecosystems 46, 3: 157-167

Boisson J, Ruttens A, Mench M, Vangronsveld J (1999a) Evaluation of hydroxyapatite as a metal immobilizing soil additive for the remediation of polluted soils. Environmental Pollution 104, 2 :225-233

Boisson J, Ruttens A, Mench M, Vangronsveld J (1999b) Immobilization of trace metals and arsenic by different soil additives: evaluation by means of chemical extractions. Communication in Soil Science and Plant Analysis $30,3-4: 365-387$

Bolan NS, Duraisamy VP (2003) Role of inorganic and organic soil amendments on immobilisation and phytoavailability of heavy metals: a review involving specific case studies. Australian Journal of Soil Research $41,3: 533-555$

Bolan NS, Adriano DC, Naidu R (2003) Role of phosphorus in (im)mobilization and bioavailability of heavy metals in the soil-plant system. Reviews of Environmental Contamination and Toxicology 177:1-44

Brallier S, Harrison RB, Henry CL, Dongsen X (1996) Liming effects on availability of Cd, Cu, Ni and Zn in a soil amended with sewage sludge 16 years previously. Water, Air, and Soil Pollution 86,1-4:195-206

Brown S, Chaney R, Angle, JS (1997) Subsurface liming and metal movement in soils amended with limestabilized biosolids. Journal of Environmental Quality 26:724-732

Brown TT, Koenig RT, Huggins DR, Harsh JB, Rossi RE (2008) Lime effects on soil acidity, crop yield and aluminum chemistry in inland Pacific Northwest direct-seed cropping systems. Soil Science Society of America Journal 72:34-640

Carvalho-Pupatto JG, Bull LT, Crusciol CAC (2004) Soil chemical attributes, root growth and rice yield according to slag application. Pesquisa Agropecuaria Brasileria 39:1213-1218

Ciesielski H, Sterckeman T (1997) Determination of cation exchange capacity and exchangeable cations in soils by means of cobalt hexamine trichloride. Effects of experimental conditions. Agronomie 17:1-7

Ciesielski H, Proix N, Sterckeman T (1997) Determination of errors due to a method of dissolution of soil and sediment. An interlaboratory study. Analusis 25, 6:188-192 
Cuin TA (2006) Calcium and oxidative stress. In Advances in Plant Physiology, Hemantaranjan (Ed), Scientific editor, Jodhpur 9:41-66

Dimitrova S (1996) Metal sorption on blast furnace slag. Water Research 30, 1:228-232

Dimitrova S, Mehandjiev D (1998) Lead removal from aqueous solutions by granulated blast-furnace slag. Water Research 32, 11:3289-3292

Fendorf E (1995) Surface reactions of chromium in soils and waters, Geoderma 67:55-71

Fessenden RJ, Sutherland BJ (1979) The effect of excess soil copper on the growth of black spruce and green alder seedlings. Botanical Gazette 140:582-587

Freeman MH, McIntyre CR (2008) A comprehensive review of copper-based wood preservatives - With a focus on new micronized or dispersed copper systems. Forest Prod. J. $58: 6-27$

Gabrielli dos Santos GC, Rodella AA, Aparecida de Abreu C, Coscione AR (2010) Vegetable species for phytoextraction of boron, copper, lead, manganese and zinc from contaminated soil. Sci. Agric. (Piracicaba, Braz.) 67, 6:713-719

Gahan CS, Cunha ML,Sandström $\AA$ (2009) Comparative study on different steel slags as neutralising agent in bioleaching. Hydrometallurgy 95:190-197

Gardener's Network (2009) pH levels in garden soils, pH levels for vegetables. http://www.gardenersnet.com/atoz/phlevel1.htm. Accessed 8 May 2011

Girouard E, Zagury GJ (2009) Arsenic bioaccessibility in CCA-contaminated soils: Influence of soil properties, arsenic fractionation, and particle-size fraction. Science of the Total Environment 407, 8:2576-2585

Gray CW, Dunham SJ, Dennis PG, Zhao FJ, McGrath SP (2006) Field evaluation of in situ remediation of a heavy metal contaminated soil using lime and red-mud. Environmental Pollution 142, 3:530-539

He ZL, Yang XE, Stoffella PJ (2005) Trace elements in agroecosystems and impacts on the environment. Biology and Medicine of Trace Elements 19, 2-3:125-140

Laboratoire d'analyses des sols d'Arras, INRA (2007) Méthodes employées au laboratoire.. http://www.lille.inra.fr/las/methodes_d_analyse/sols. Accessed 06 May 2010

Jackson ML (1967) Soil Chemical Analysis, Prentice-Hall., Inc., Englewood Cliffs, New Jersey, USA.

Jackson ML (1969) Soil Chemical Analysis- advanced course $2^{\text {nd }}$ edition. Departement of Soil Sciences. University of Wisconsin, Madison, USA.

Jamali KSF, Forghani A (2008) Using by-products of steelmaking industry as amendments to correct soil pH, and their effects on some heavy element in soil and tea leaves. Agricultural Science (Tabriz), 18, 3:84-99 
Karjalainen A, Kilpi-Koski J, Vaisanen A, Penttinen S, Gestel C, Penttinen O (2009) Ecological risks of an old wood impregnation mill: application of the Triad approach. Integrated Environmental Assessment and Management 5:379-389

Kim DH, Shin MC, Choi HD, Seo CI, Baek K (2008) Removal mechanisms of copper using steel-making slag: adsorption and precipitation. Desalination 223, 1-3:283-289

Kolbas A, Mench M Herzig R, Nehnevajova E, Bes CM (2011) Copper phytoextraction in tandem with oilseed production using commercial cultivars and mutant lines of sunflower. International Journal Phytoremediation (DOI: $10.1080 / 15226514.2011 .568536)$.

Krebs R, Gupta SK, Furrer G, Schulin R (1998) Solubility and plant uptake of metals with and without liming of sludge-amended soils. Journal of Environmental Quality 27:18-23

Kumpiene J, Ore S, Renella G, Mench M, Lagerkvist A, Maurice C (2006) Assessment of zerovalent iron for stabilization of chromium, copper, and arsenic in soil. Environmental Pollution 144, 1:62-69

Kumpiene J, Lagerkvist A, Maurice C (2008) Stabilization of As, Cr, Cu, $\mathrm{Pb}$ and $\mathrm{Zn}$ in soil using amendments A review. Waste Management 28, 1:215-225

Liu R, Zhao D (2007) In situ immobilization of $\mathrm{Cu}$ (II) in soils using a new class of iron phosphate nanoparticles. Chemosphere 68, 10:1867-1876

MacNicol RD, Beckett PHT (1985) Critical tissue concentrations of potentially toxic elements. Plant and Soil $85,1: 107-129$

Ma Q (1996) Factors influencing the effectiveness and stability of aqueous lead immobilization by hydroxyapatite. Journal of Environmental Quality 25:1420-1429

Marschner H (1995) Mineral Nutrition in Higher Plants, $2^{\text {nd }}$ ed. Academic Press, London

Mathieu A, Baize D, Raoul C, Daniau C (2008) Proposition de référentiels régionaux en éléments traces métalliques dans les sols: leur utilisation dans les évaluations des risques sanitaires. Environnement, Risques \& Santé 7, 2:112-122

Mench M, Didier V, Löffler M, Gomez A, Masson P (1994a) A mimicked in-situ remediation study of metalcontaminated soils with emphasis on cadmium and lead. Journal of Environmental Quality 23:58-63.

Mench M, Vangronsveld J, Didier V, Clijsters H (1994b). Evaluation of metal mobility, plant availability and immobilization by chemical agents in a limed-silty soil. Environmental Pollution 86, 3:279-286

Mench M, Coussin F, Mocquot B, Bussière S, Prunet T, Lagriffoul A (1996) Evaluation des apports d'un biotest végétal et de la spéciation des éléments traces à la mise au point d'une batterie de tests d'écotoxicologie terrestre 
applicables aux sols et aux déchets. Final report n4930029, INRA, Unité d'Agronomie, Bordeaux - ADEME, Recherche, Milieux et Impact, Paris, France

Mench M, Vangronsveld J, Lepp NW, Edwards R (1998) Physico-chemical aspects and efficiency of trace element immobilisation by soil amendments. In In situ inactivation and phytorestoration of metal-contaminated soils. Vangronsveld J. and Cunningham S.D. (Eds) Landes Biosciences, Georgetown, Texas, pp 151-182

Mench M, Manceau A, Vangronsveld J, Clijsters H, Mocquot (2000) Capacity of soil amendments in lowering the phytoavailability of sludge-borne zinc. Agronomie 20:383-397

Mench M, Vangronsveld J, Lepp N, Bleeker P, Ruttens A, Geebelen W (2006) Phytostabilisation of metalcontaminated sites. Phytoremediation of Metal-Contaminated Soils, In Echevarria G, Morel JL, Goncharova N (eds.), NATO Science Series: IV: Earth and Environmental Sciences 68, Springer, Dordrecht, Netherlands, pp $109-190$

Mench M, Bes C (2009) Assessment of the ecotoxicity of topsoils from a wood treatment site. Pedosphere $19: 143-155$

Mench M, Bert V, Schwitzguébel JP, Lepp N, Schröder P, Gawronski S, Vangronsveld J (2010) Successes and limitations of phytotechnologies at field scale: Outcomes, assessment and outlook from COST Action 859. Journal Soils Sediments 10:1039-1070

Micheli F (2001) Pectin methylesterases: cell wall enzymes with important roles in plant physiology. Trends in Plant Science 6, 9:414- 419

Omafra. B (2008) The Gardener's Handbook. Chapter 4. The Nature of Soil. Look to the Ground. http://www.omafra.gov.on.ca/english/crops/gardbk/4soil.htm\#table7. Accessed 4 May 2011

Oste L, Lexmond TM, Riemsdijk WH (2002) Metal immobilization in soils using synthetic zeolites. Journal of Environmental Quality 31, 3:813-821

Pérez de Mora A, Ortega-Calvo JJ, Cabrera E, Madejón E (2005) Changes in enzyme activities and microbial biomass after "in situ" remediation of a heavy metal-contaminated soil. Applied Soil Ecology 28, 2:125-137

Pierzynski GM, Schwab AP (1993) Bioavailability of zinc, cadmium, and lead in a metal-contaminated alluvial soil. Journal of Environmental Quality 22, 2:247-254

Pilon M, Abdel-Ghany SE, Cohu CM, Gogolin KA, Ye H (2006) Copper cofactor delivery in plant cells. Current Opinion in Plant Biology 9, 3:256-263 
Pinto M, Rodriguez M, Besga GKK, Lopez FA (1995) Effects of Linz-Donawitz (LD) slag on soil properties and pasture production in the Basque country (Northern Spain). New Zealand Journal of Agricultural Research $38,1: 143-155$

Proctor DM, Shay EC, Fehling KA, Finley BL (2002) Assessment of human health and ecological risks posed by the uses of steel-industry slags in the environment. Human and Ecological Risk Assessment, 8, 4:681-711

Raicevic S, Kaludjerovic-Radoicic T, Zouboulis AI (2005) In situ stabilization of toxic metals in polluted soils using phosphates: theoretical prediction and experimental verification. Journal of Hazardous Materials 117 , $1: 41-53$

Richards LA (1954) Diagnosis and improvement of saline and alkali soil. United States Department of Agriculture, Handbook 60

Sinaj S, Frossard E, Fardeau JC, Lhote F, Morel JL (1994) Observation directe de l'altération de scories de déphosphoration après incorporation dans un sol acide cultivé. Comptes Rendus de l'Académie des Sciences de Paris, 319 série II :1207-1214

Singh BR, Oste L (2001) In situ immobilization of metals in contaminated or naturally metal-rich soils. Environmental Reviews 9, 2:81-97

Sipos P, Nemeth T, Kis VK, Mohai I (2008) Sorption of copper, zinc and lead on soil mineral phases. Chemosphere $73,4: 461-469$

Su C, Evans LJ (1996) Soil solution chemistry and alfalfa response to $\mathrm{CaCO}_{3}$ and $\mathrm{MgCO}_{3}$ on an acidic Gleysol. Canadian Journal of Soil Science 76, 1:41-46

Tlustoš P, Száková J, Kořínek K, Pavlíková D, Hanč A, Balík J (2006) The effect of liming on cadmium, lead, and zinc uptake reduction by spring wheat grown in contaminated soil. Plant Soil and Environment 52, 1:16-24 Tyler LD, McBride MB (1982) Mobility and extractability of cadmium, copper, nickel and zinc in organic and mineral soil columns. Soil Science 134, 3:198-205

Wang YM, Chen TC, Yeh KJ, Shue MF (2001) Stabilization of an elevated heavy metal contaminated site. Journal of Hazardous Materials 88, 1:63-74

Wright KE (1937) Effects of phosphorus and lime in reducing aluminum toxicity of acid soils. Plant Physiology $12,1: 173-181$

Xu Y, Schwartz FW, Traina SJ (1994) Sorption of $\mathrm{Zn}^{2+}$ and $\mathrm{Cd}^{2+}$ on hydroxyapatite surfaces. Environmental Science and Technology 28, 8:1472-1480 
Yilmaz D, Lassabatere L, Angulo-Jaramillo R, Deneele D, Legret M (2010) Hydrodynamic characterization of basic oxygen furnace slag through an adapted BEST method. Vadose Zone Journal 9:107-116 